\title{
Height-Age Relationships for Regeneration-Size Trees in the Northern Rocky Mountains, USA
}

Dennis E. Ferguson and Clinton E. Carlson
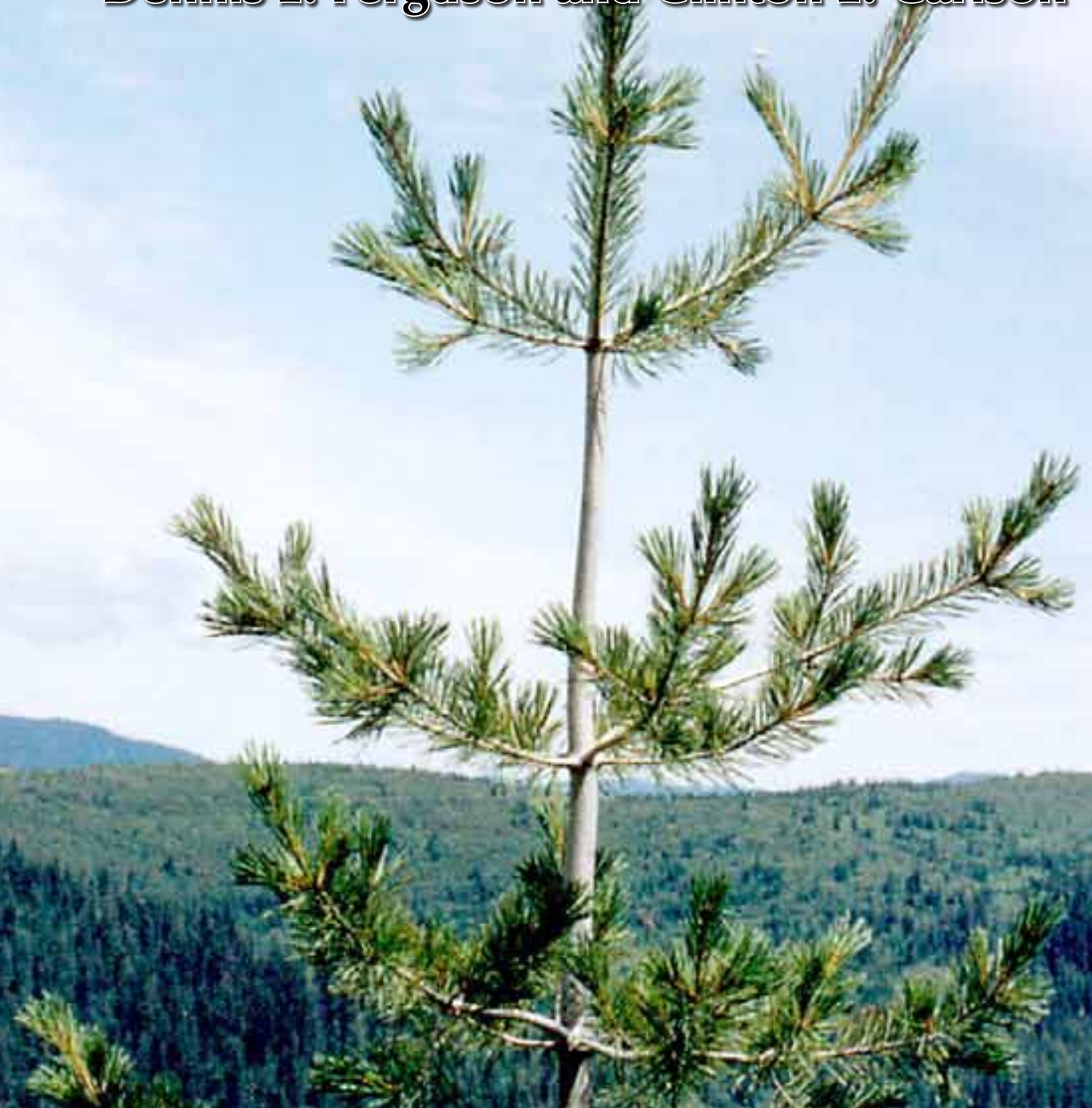

Fis

USDA United States Department of Agrictilture / Forest Servicesty

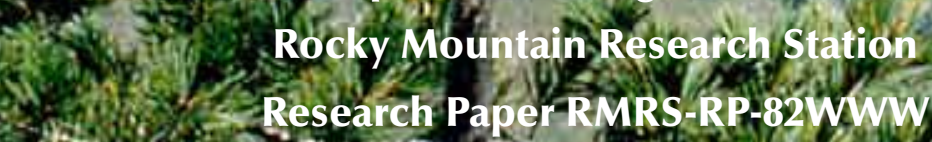

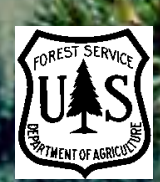

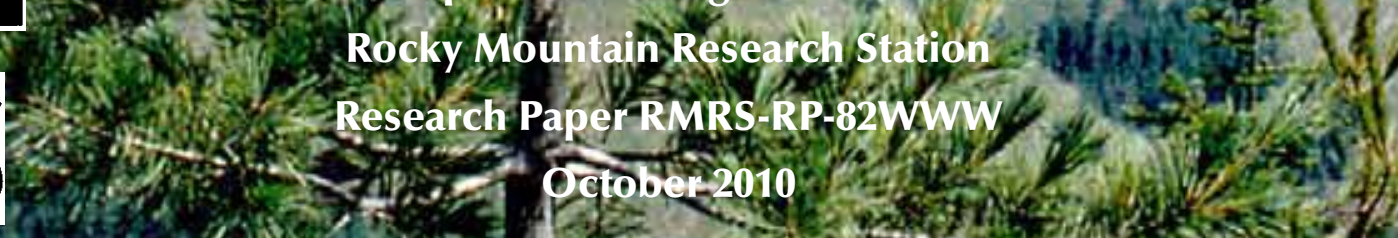


Ferguson, Dennis E.; Carlson, Clinton E. 2010. Height-age relationships for regeneration-size trees in the northern Rocky Mountains, USA. Res. Pap.

RMRS-RP-82WWW. Fort Collins, CO: U.S. Department of Agriculture, Forest

Service, Rocky Mountain Research Station. 19 p.

\section{AbStRact}

Regression equations were developed to predict heights of 10 conifer species in regenerating stands in central and northern Idaho, western Montana, and eastern Washington. Most sample trees were natural regeneration that became established after conventional harvest and site preparation methods. Heights are predicted as a function of tree age, residual overstory density, elevation, site preparation, habitat type series, and closest National Forest location. Equations are presented that can be used to predict heights at a given age or to predict the number of years required to reach a specified height.

Keywords: forest succession, conifer growth, natural regeneration, forest management, habitat types

\section{AuthORS}

Dennis E. Ferguson is a Research Silviculturist with the USDA Forest Service, Rocky Mountain Research Station in Moscow, Idaho.

Clinton E. Carlson is a Research Silviculturist (retired) with the Rocky Mountain Research Station in Missoula, Montana.

\section{ACKNOWLEDGMENTS}

We thank Raymond J. Boyd, Ward W. McCaughey, and Leon Theroux for their help with study design and data collection.

Available only online at http://www.fs.fed.us/rm/pubs/rmrs_rp082.html

\section{Rocky Mountain Research Station Publishing Services}

$\begin{aligned} \text { Telephone } & \text { (970) 498-1392 } \\ \text { FAX } & (970) 498-1122 \\ \text { E-mail } & \text { rschneider@fs.fed.us } \\ \text { Web site } & \text { http://www.fs.fed.us/rm/publications } \\ \text { Mailing address } & \text { Publications Distribution } \\ & \text { Rocky Mountain Research Station } \\ & \text { 240 West Prospect Road } \\ & \text { Fort Collins, CO } 80526\end{aligned}$




\section{Introduction}

Secondary succession that follows disturbance is a period of rapid change in northern Rocky Mountain forest environments. During this period, shrubs, forbs, and grasses are responding to increased sunlight, moisture, and nutrients. Several conifer and a few deciduous tree species are regenerating, and residual overstory trees are adjusting to changes in stand conditions. All these vegetative lifeforms are competing within and among themselves to various degrees.

Also, many chance occurrences can play a role in altering the direction of secondary succession in regenerating stands. Among these factors are weather patterns, seed and cone insects, seed predation, small mammal activity, animal browsing, various diseases, and abiotic damages. Silvicultural treatments to favor conifers such as shrub control, thinnings, and plantings can have substantial impacts on succession that last for many decades.

It is important in the northern Rocky Mountains to understand conifer height-age relationships during the approximately 20 -yr regeneration period that follows disturbance. The information can be used to estimate regeneration heights, determine the number of years for regeneration to reach breast height $(4.5 \mathrm{ft})$ or conversely estimate total tree age from breast height age, and make decisions about the need for treatments to control competition.

This report provides information on regeneration height-age relationships for 10 conifer species in central and northern Idaho, western Montana, and part of eastern Washington. These data have been reported elsewhere (Ferguson and others 1986; Ferguson and Carlson 1993), but new analytical techniques are now available that improve predictions of heightage relationships.

\section{Study Design}

The data come from three studies that looked at regeneration success following timber harvest in the northern Rocky Mountains. The first study was conducted in the grand fir (Abies grandis), western redcedar (Thuja plicata), and western hemlock (Tsuga heterophylla) habitat types of northern Idaho during 1975 to 1976 and was used to develop version 1 of the regeneration establishment model (Ferguson and others 1986). Data were collected during a second study in central Idaho Douglas-fir (Pseudotsuga menziesii), grand fir, and subalpine fir (Abies lasiocarpa) habitat types, and from Douglas-fir and subalpine fir habitat types in northern Idaho during 1979 to 1982. Data were collected during the third study in Douglas-fir, grand fir, western redcedar, western hemlock, and subalpine fir habitat types in western Montana during 1979 to 1982. Data from studies 2 and 3 were combined with data from study 1 to develop version 2 of the regeneration establishment model (Ferguson and Carlson 1993).

A stratified random design was used to select stands that were harvested 2 to $20 \mathrm{yr}$ prior to sampling. Stratification variables were habitat type series, site preparation, and regeneration method. In studies 2 and 3, history of western spruce budworm (Choristoneura occidentalis) defoliation was also a classification variable. Although stands were used to select study areas, the focus was on sampling microsites within stands.

After obtaining stand histories and stereo aerial photographs for each selected stand from Ranger District files, either transects or a sampling grid was used to systematically locate about 25 plot centers per stand. In Idaho, transects crossed through areas observable on aerial photographs that varied in aspect, overstory density, site preparation, or topographic position. In Montana, a sampling grid was used to locate plot centers.

Each sample point was the center of a 1/300-acre circular fixed area plot and a variable radius plot for sampling the overstory (if present) with a 10 basal area factor prism. Each plot was made as independent as possible by recording plot attributes: slope, aspect, 
type of site preparation, topographic position, residual overstory density by species, and habitat type (Cooper and others 1991; Pfister and others 1977; Steele and others 1981). Systematically spacing plots also helped maintain independence among plots within stands because plots were dispersed throughout the stand. The year of harvest, geographic location, and elevation were stand variables that did not differ among plots within a stand.

Within the same stand, plots could have different "years since last disturbance" due to the timing of site preparation. Untreated plots were last disturbed when the stand was harvested. Mechanically prepared or burned plots were last disturbed when the site preparation took place, which could have occurred after the harvest year.

All established conifer regeneration on plots in the Idaho studies was counted by species; in Montana, up to 10 established trees were recorded per plot. Minimum heights were $0.5 \mathrm{ft}$ for shade-tolerant species and $1.0 \mathrm{ft}$ for shade-intolerant species, which roughly correspond to the heights of 3-yr-old trees. Maximum size for all regeneration was 3.0 inches diameter at breast height (dbh). Tree heights were measured as of the end of the previous growing season to ensure that all trees were sampled during a field season by the same criterion.

Tree height to the nearest $0.1 \mathrm{ft}$, tree age at groundline (end of the previous growing season), and tree condition were recorded on a subsample of regeneration called best trees, which were chosen by the following rules:

- Select the two tallest trees on the plot regardless of species.

- Select the one tallest tree of each additional species present on the plot.

- If the first two rules do not result in at least four trees, select in order of descending height from any remaining trees until four trees, if present, are chosen.

Shrubs, forbs, and grasses were characterized by recording average height and percent plot coverage, similar to Daubenmire (1959). These data were not used to predict regeneration heights because it was not possible to retrospectively determine coverage during the life of the tree; however, the Idaho data were used to develop a model of secondary succession for shrubs, forbs, and grasses (Moeur 1985).

\section{Data Analysis}

Data were analyzed with SAS version 9.2 using methods for mixed models (Littell and others 1996). PROC MIXED was used to predict regeneration heights as a function of age, site variables, and overstory competition. Study areas were designated as a random variable because each site represented a sample from a larger set of possible sites. The SUBJECT statement was used to account for the correlation among plots within stands.

The significance of independent variables was evaluated using t-ratios and F-values at the $\mathrm{P}=0.05$ level. Akaike's information criteria (AIC; smaller is better) was used to compare models that had different independent variables but the same dependent variable. Transformations of variables were explored to achieve homogeneity of error variance and obtain additivity of effects (Kirk 1982). Preliminary analyses showed that the natural log (ln) of height and age were the best transformation for these two variables.

Stands were assigned to a class variable for the nearest U.S. Forest Service National Forest (NF). Other researchers have found NF useful in modeling forest growth because it divides the study area into units that can account for variation in latitude, longitude, climate, and soil (Ferguson and Carlson 1993; Wykoff 1982, 1986). The interaction of aspect and slope was modeled after Stage (1976).

Before fitting regression equations, the data were screened to exclude advance regeneration (trees that had germinated more than $3 \mathrm{yr}$ before the harvest). Also eliminated were tree species with only a few observations, which resulted in 10 conifer species available 
Table 1. Common name, scientific name, and abbreviation for conifer species in this study.

\begin{tabular}{|c|c|c|c|}
\hline $\begin{array}{l}\text { Common } \\
\text { name }\end{array}$ & $\begin{array}{l}\text { Scientific } \\
\text { name }\end{array}$ & Abbreviation & $\begin{array}{c}\text { Minimum } \\
\text { establishment } \\
\text { height (ft) }\end{array}$ \\
\hline Ponderosa pine & $\begin{array}{l}\text { Pinus ponderosa Dougl. } \\
\text { ex Laws. var. ponderosa }\end{array}$ & PP & 1.0 \\
\hline Western larch & Larix occidentalis Nutt. & WL & 1.0 \\
\hline Lodgepole pine & $\begin{array}{l}\text { Pinus contorta Dougl. } \\
\text { ex Loud. }\end{array}$ & LP & 1.0 \\
\hline Engelmann spruce & $\begin{array}{l}\text { Picea engelmannii Parry } \\
\text { ex Engelm. }\end{array}$ & ES & 0.5 \\
\hline Douglas-fir & $\begin{array}{l}\text { Pseudotsuga menziesii } \\
\text { var. glauca (Beissn.) } \\
\text { Franco }\end{array}$ & DF & 1.0 \\
\hline Western white pine & $\begin{array}{l}\text { Pinus monticola Dougl. } \\
\text { ex D. Don }\end{array}$ & WP & 1.0 \\
\hline Grand fir & $\begin{array}{l}\text { Abies grandis (Dougl. } \\
\text { ex D. Don) Lindl. }\end{array}$ & GF & 0.5 \\
\hline Western hemlock & $\begin{array}{l}\text { Tsuga heterophylla } \\
\text { (Raf.) Sarg. }\end{array}$ & WH & 0.5 \\
\hline Subalpine fir & $\begin{array}{l}\text { Abies lasiocarpa } \\
\text { (Hook.) Nutt. }\end{array}$ & AF & 0.5 \\
\hline Western redcedar & $\begin{array}{l}\text { Thuja plicata Donn } \\
\text { ex D. Don }\end{array}$ & $\mathrm{RC}$ & 0.5 \\
\hline
\end{tabular}

for analyses. Table 1 shows common and scientific names of conifer species in this study, as well as minimum establishment heights.

Visual inspection of height-age plots revealed a bias in the sample design because mean tree height increased with increasing age, but then unexpectedly declined beyond a certain age. It is likely that tall trees were absent at older tree ages because they had grown beyond the $3.0 \mathrm{dbh}$ threshold. A combination of inspection of height-age plots by species and examination of mean heights by age by species was used to reveal ages beyond which the data were suspect. Therefore, trees were eliminated with ages beyond $13 \mathrm{yr}$ for western larch; 14 yr for Douglas-fir; 15 yr for ponderosa pine, western white pine, and western redcedar; $16 \mathrm{yr}$ for lodgepole pine; $17 \mathrm{yr}$ for Engelmann spruce and grand fir; $18 \mathrm{yr}$ for western hemlock; and $20 \mathrm{yr}$ for subalpine fir.

\section{Results}

A total of 8824 trees were used in the analyses. Table 2 shows the number of trees by species, habitat type series, NF, and site preparation. A summation of the number of trees by geographic area shows that 686 trees were sampled in central Idaho, 5721 trees in northern Idaho, 227 trees in eastern Washington, and 2190 trees in western Montana. Western hemlock had the fewest trees in the sample (346), and grand fir had the most (3100), comprising about one-third of the total number of trees.

It is clear from Table 2 that height estimates cannot be made for all combinations of species and NF locations. Species do not occur uniformly across the landscape, and even where they do occur, their occurrence is low toward the extremes of their environmental niche (Daubenmire 1966; Rehfeldt and others 2008). 
Table 2. Number of sample trees by species, habitat type series, National Forest location, and site preparation. Species are listed in the approximate order of shade tolerance, from least (left) to most tolerant (right). Species definitions are found in Table 1.

\begin{tabular}{|c|c|c|c|c|c|c|c|c|c|c|c|}
\hline \multirow{2}{*}{$\begin{array}{l}\text { Habitat type } \\
\text { series* }\end{array}$} & \multicolumn{11}{|c|}{ Species } \\
\hline & PP & WL & LP & ES & DF & WP & GF & WH & AF & RC & Total \\
\hline PSME & 252 & 55 & 106 & 4 & 251 & 0 & 8 & 0 & 1 & 0 & 677 \\
\hline ABGR & 256 & 131 & 190 & 92 & 427 & 46 & 899 & 0 & 22 & 6 & 2069 \\
\hline THPL & 57 & 94 & 62 & 76 & 299 & 129 & 1205 & 2 & 21 & 308 & 2253 \\
\hline TSHE & 2 & 97 & 90 & 93 & 264 & 160 & 834 & 337 & 61 & 137 & 2075 \\
\hline ABLA & 33 & 163 & 394 & 335 & 246 & 20 & 154 & 7 & 396 & 2 & 1750 \\
\hline National Forest & PP & WL & LP & ES & DF & WP & GF & WH & AF & RC & Total \\
\hline Bitterroot & 51 & 5 & 36 & 6 & 62 & 0 & 3 & 0 & 15 & 0 & 178 \\
\hline Boise & 113 & 0 & 48 & 16 & 27 & 0 & 26 & 0 & 3 & 0 & 233 \\
\hline Clearwater & 32 & 50 & 54 & 133 & 323 & 137 & 1152 & 0 & 59 & 209 & 2149 \\
\hline Colville & 3 & 10 & 63 & 2 & 49 & 1 & 76 & 6 & 3 & 14 & 227 \\
\hline Deerlodge & 2 & 45 & 25 & 5 & 83 & 0 & 0 & 0 & 5 & 0 & 165 \\
\hline Flathead & 0 & 81 & 18 & 6 & 64 & 4 & 10 & 0 & 7 & 0 & 190 \\
\hline Gallatin & 0 & 0 & 96 & 7 & 17 & 0 & 0 & 0 & 5 & 0 & 125 \\
\hline Helena & 0 & 0 & 55 & 0 & 67 & 0 & 0 & 0 & 10 & 0 & 132 \\
\hline Kootenai & 19 & 83 & 62 & 43 & 51 & 33 & 33 & 25 & 64 & 30 & 443 \\
\hline Lolo & 150 & 167 & 193 & 22 & 218 & 5 & 136 & 1 & 51 & 14 & 957 \\
\hline Nez Perce & 62 & 17 & 31 & 77 & 80 & 0 & 252 & 0 & 25 & 8 & 552 \\
\hline Panhandle & 2 & 75 & 110 & 220 & 402 & 175 & 1333 & 314 & 211 & 178 & 3020 \\
\hline Payette & 166 & 7 & 51 & 63 & 44 & 0 & 79 & 0 & 43 & 0 & 453 \\
\hline Site preparation & PP & WL & LP & ES & DF & WP & GF & WH & AF & RC & Total \\
\hline None & 149 & 133 & 250 & 69 & 586 & 163 & 1560 & 181 & 184 & 178 & 3453 \\
\hline Mechanical & 222 & 161 & 325 & 202 & 351 & 81 & 631 & 64 & 133 & 84 & 2254 \\
\hline Burn & 192 & 197 & 219 & 259 & 447 & 65 & 638 & 70 & 134 & 107 & 2328 \\
\hline Roads & 37 & 49 & 48 & 70 & 103 & 46 & 271 & 31 & 50 & 84 & 789 \\
\hline Total & 600 & 540 & 842 & 600 & 1487 & 355 & 3100 & 346 & 501 & 453 & 8824 \\
\hline
\end{tabular}

${ }^{*} \mathrm{PSME}=$ Pseudotsuga menziesii habitat type series. $\mathrm{ABGR}=$ Abies grandis series. $\mathrm{THPL}=$ Thuja plicata series. TSHE $=$ Tsuga heterophylla series. $\mathrm{ABLA}=$ Abies lasiocarpa series.

\section{Height-age equations}

Table 3 lists variables used in regression analyses to predict regeneration heights. Table 4 shows multiple regression equations for predicting height from age, residual basal area, elevation, slope, habitat type series, NF, and site preparation. Interpretation of the partial regression coefficients can be done with all other variables in the equation being held constant.

Tree age is the best predictor of height. The smallest coefficients (shorter trees) for age are subalpine fir and western redcedar. Shade-intolerant species - ponderosa pine, western larch, lodgepole pine, Engelmann spruce, Douglas-fir, and western white pine- had larger coefficients than subalpine fir and western redcedar. Western hemlock had the largest coefficient for age of the 10 species.

For all species except Engelmann spruce, residual basal area was associated with shorter heights when all other variables were held constant (Table 4). Western redcedar heights were least negatively impacted by residual overstory basal area, while ponderosa pine and lodgepole pine had the largest reductions in heights associated with basal area.

Increasing elevation was associated with shorter heights for western larch, lodgepole pine, western white pine, grand fir, western hemlock, and western redcedar when all other variables were held constant (Table 4). Overall, the interaction of slope and aspect was not a significant predictor of tree heights, but slope was important for lodgepole pine and grand fir. 
Table 3. List of variables used in analyses of data, means, and extreme values.

\begin{tabular}{llcc}
\hline Abbreviation & \multicolumn{1}{c}{ Explanation } & Mean & Min/Max \\
\hline height & Tree height (ft) & 2.5 & 0.5 to 22.9 \\
age & Tree age at groundline $(\mathrm{yr})$ & 8.5 & 3 to 19 \\
ba & Residual plot basal area ( $\left.\mathrm{ft}^{2} / \mathrm{acre}\right)$ & 18.5 & 0 to 380 \\
elev & Stand elevation (nearest 100 ft) & 46.9 & 24 to 74 \\
slo & Plot slope ratio (percent/100) & 0.23 & 0 to 0.99 \\
delay & Number of years from harvesting & 2.2 & -3 to 17 \\
& $\begin{array}{l}\text { or site preparation to germination } \\
\text { of the tree }\end{array}$ & & \\
\hline
\end{tabular}

Table 4. Coefficients for equations that predict tree heights. The form of the equation is:

Height $=\exp \left(\beta_{0}+\sum \beta_{i} X_{i}\right)$. Height is tree height in feet, age is tree age at groundline, ba is point basal area in $\mathrm{ft}^{2} / a c r e$, elev is stand elevation to the nearest $100 \mathrm{ft}$, slo is plot slope ratio (percent/100); and PSME is Douglas-fir habitat types, ABGR is grand fir habitat types, THPL is western redcedar habitat types, TSHE is western hemlock habitat types, and ABLA is subalpine fir habitat types. Road site preparation includes plots that occurred on road cuts, road fills, and unmaintained road beds.

\begin{tabular}{|c|c|c|c|c|c|c|c|c|c|c|}
\hline Variable & PP & WL & LP & ES & DF & WP & GF & WH & AF & RC \\
\hline $\begin{array}{l}ß_{0} \\
\text { In(age) } \\
\text { ba } \\
\text { elev } \\
\text { slo }\end{array}$ & $\begin{array}{r}-1.7936 \\
1.3737 \\
-0.0052\end{array}$ & $\begin{array}{r}-0.8617 \\
1.3093 \\
-0.0038 \\
-0.0136\end{array}$ & $\begin{array}{r}-1.0935 \\
1.3836 \\
-0.0070 \\
-0.0099 \\
-0.6632\end{array}$ & $\begin{array}{r}-2.5216 \\
1.3595\end{array}$ & $\begin{array}{r}-2.1325 \\
1.3167 \\
-0.0030\end{array}$ & $\begin{array}{r}-1.2269 \\
1.2842 \\
-0.0031 \\
-0.0182\end{array}$ & $\begin{array}{r}-1.8619 \\
1.2260 \\
-0.0034 \\
-0.0048 \\
-0.2329\end{array}$ & $\begin{array}{r}-1.8742 \\
1.5824 \\
-0.0038 \\
-0.0173\end{array}$ & $\begin{array}{r}-2.0991 \\
1.1671 \\
-0.0033\end{array}$ & $\begin{array}{r}-1.3326 \\
1.0819 \\
-0.0021 \\
-0.0118\end{array}$ \\
\hline $\begin{array}{l}\text { Habitat type } \\
\text { PSME } \\
\text { ABGR } \\
\text { THPL } \\
\text { TSHE } \\
\text { ABLA }\end{array}$ & $\begin{array}{r}\text { series } \\
-0.0852 \\
0.0885 \\
0.1364 \\
0.1364^{*} \\
0.0\end{array}$ & & $\begin{array}{r}-0.1708 \\
0.1289 \\
0.1889 \\
0.1059 \\
0.0\end{array}$ & $\begin{array}{r}0.1665^{*} \\
0.1665 \\
0.1522 \\
0.2160 \\
0.0\end{array}$ & $\begin{array}{r}-0.0137 \\
0.1287 \\
0.2820 \\
0.2284 \\
0.0\end{array}$ & N.D. & $\begin{array}{r}\text { N.D. } \\
0.0 \\
0.1525 \\
0.0 \\
0.0\end{array}$ & $\begin{array}{l}\text { N.D. } \\
\text { N.D. } \\
\text { * }\end{array}$ & * & $\begin{array}{r}\text { N.D. } \\
\text { * }\end{array}$ \\
\hline $\begin{array}{l}\text { National Fo } \\
\text { Bitterroot } \\
\text { Boise } \\
\text { Clearwater } \\
\text { Colville } \\
\text { Deerlodge } \\
\text { Flathead } \\
\text { Gallatin } \\
\text { Helena } \\
\text { Kootenai } \\
\text { Lolo } \\
\text { Nez Perce } \\
\text { Payette } \\
\text { Panhandle }\end{array}$ & $\begin{array}{r}\text { est } \\
-0.2393 \\
-0.2857 \\
0.0 \\
0.0^{*} \\
-.2393^{*} \\
\text { N.D. } \\
\text { N.D. } \\
\text { N.D. } \\
-0.2393 \\
-0.3803 \\
-0.2092 \\
-0.4394 \\
0.0^{*}\end{array}$ & $\begin{array}{r}-0.0249 \\
\text { N.D. } \\
0.0915 \\
0.0 \\
-0.0249 \\
-0.1683 \\
\text { N.D. } \\
\text { N.D. } \\
0.2030 \\
-0.0770 \\
0.0773 \\
0.0773^{*} \\
0.0\end{array}$ & $\begin{array}{r}0.1759 \\
-0.1365 \\
0.1759 \\
-0.1365 \\
-0.0658 \\
0.0594 \\
0.0594 \\
0.0594 \\
-0.1905 \\
-0.0658 \\
0.1759 \\
-0.2332 \\
0.0\end{array}$ & $\begin{array}{r}-.3367^{*} \\
-0.2387 \\
-0.1386 \\
0.0^{*} \\
-.3367^{*} \\
-.3367^{*} \\
-.3367^{*} \\
\text { N.D. } \\
0.0248 \\
-0.3367 \\
0.0872 \\
-0.2387 \\
0.0\end{array}$ & $\begin{array}{r}-0.4759 \\
-0.2399 \\
0.0085 \\
-0.1247 \\
-0.3972 \\
-0.2223 \\
-0.6311 \\
-0.6311 \\
-0.0725 \\
-0.4539 \\
0.0193 \\
-0.2851 \\
0.0\end{array}$ & 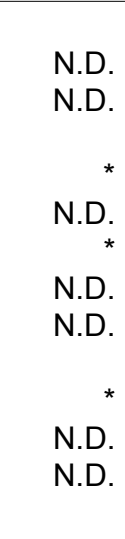 & $\begin{array}{r}-.0734^{*} \\
-0.4095 \\
-0.0368 \\
-0.1171 \\
\text { N.D. } \\
-0.0734 \\
\text { N.D. } \\
\text { N.D. } \\
-0.0734 \\
-0.0734 \\
-0.1389 \\
-0.4095 \\
0.0\end{array}$ & $\begin{array}{l}\text { N.D. } \\
\text { N.D. } \\
\text { N.D. } \\
\text { * } \\
\text { N.D. } \\
\text { N.D. } \\
\text { N.D. } \\
\text { N.D. } \\
\quad \text { * } \\
\text { N.D. } \\
\text { N.D. }\end{array}$ & $\begin{array}{r}-0.2277 \\
-.1756^{*} \\
-0.1756 \\
0.0^{*} \\
-.2277^{*} \\
0.1866^{*} \\
-.2277^{*} \\
0.1866 \\
0.1866 \\
-0.2277 \\
-0.1756 \\
-0.1756 \\
0.0\end{array}$ & $\begin{array}{l}\text { N.D. } \\
\text { N.D. } \\
\text { N.D. } \\
\text { N.D. }\end{array}$ \\
\hline $\begin{array}{l}\text { Site prepara } \\
\text { none } \\
\text { mechanical } \\
\text { burn } \\
\text { road }\end{array}$ & $\begin{array}{r}0.0 \\
0.1642 \\
0.1372 \\
0.1262\end{array}$ & & $\begin{array}{r}0.0 \\
0.1130 \\
0.0405 \\
0.1875\end{array}$ & $\begin{array}{r}0.0 \\
0.1365 \\
0.2895 \\
0.1177\end{array}$ & $\begin{array}{r}0.0 \\
0.0144 \\
0.1517 \\
0.0829\end{array}$ & & & & & $\begin{array}{r}0.0 \\
-0.1338 \\
0.0239 \\
0.1557\end{array}$ \\
\hline $\begin{array}{l}\mathrm{n} \\
\text { AIC } \\
\text { Residual } \\
\text { Log bias } \\
\text { correction } \\
\text { factor }\end{array}$ & $\begin{array}{r}600 \\
778 \\
0.1187\end{array}$ & $\begin{array}{r}540 \\
790 \\
0.1107\end{array}$ & $\begin{array}{r}842 \\
1077 \\
0.1140\end{array}$ & $\begin{array}{r}600 \\
811 \\
0.1334\end{array}$ & $\begin{array}{r}1487 \\
2295 \\
0.1512\end{array}$ & $\begin{array}{r}355 \\
464 \\
0.1423\end{array}$ & $\begin{array}{r}3100 \\
4443 \\
0.1637\end{array}$ & $\begin{array}{r}346 \\
553 \\
0.1867\end{array}$ & $\begin{array}{r}501 \\
772 \\
0.1265\end{array}$ & $\begin{array}{r}453 \\
748 \\
0.1643\end{array}$ \\
\hline
\end{tabular}

N.D. = no data in the category.

${ }^{*}$ Fewer than 10 trees in the category; combined with another National Forest or habitat type series. 
Habitat type series was important for species with wider distributions, such as ponderosa pine, lodgepole pine, Engelmann spruce, and Douglas-fir. NF locations were important for 7 of the 10 species. Three species with relatively narrow distributions-western white pine, western hemlock, and western redcedar-had no location-specific coefficients.

Plot site preparation was a significant predictor of heights for ponderosa pine, lodgepole pine, Engelmann spruce, Douglas-fir, and western redcedar. Generally, site preparation was associated with taller trees, compared to no site preparation. Coefficients for burn site preparation were larger, compared to mechanical site preparation, for Engelmann spruce, Douglas-fir, and western redcedar.

Figures 1 through 10 show height-age curves using the equations given in Table 4 . These figures depict results of exercising the equations for two elevations (35 and 50) and four levels of residual basal area $\left(0,40,80\right.$, and $\left.120 \mathrm{ft}^{2}\right)$ while holding slope at 0 percent and using class variables for habitat type series, NF, and site preparation that have the highest number of observations shown in Table 2. The purpose of the figures is to show how height-age curves differ among species, elevations, and basal areas. Some species have only one figure because elevation was not significant in the equations, and six species do not have a $120 \mathrm{ft}^{2}$ basal area prediction because of lack of data at high densities. Each figure has a horizontal line at $4.5 \mathrm{ft}$ to aid in visually determining age at breast height.

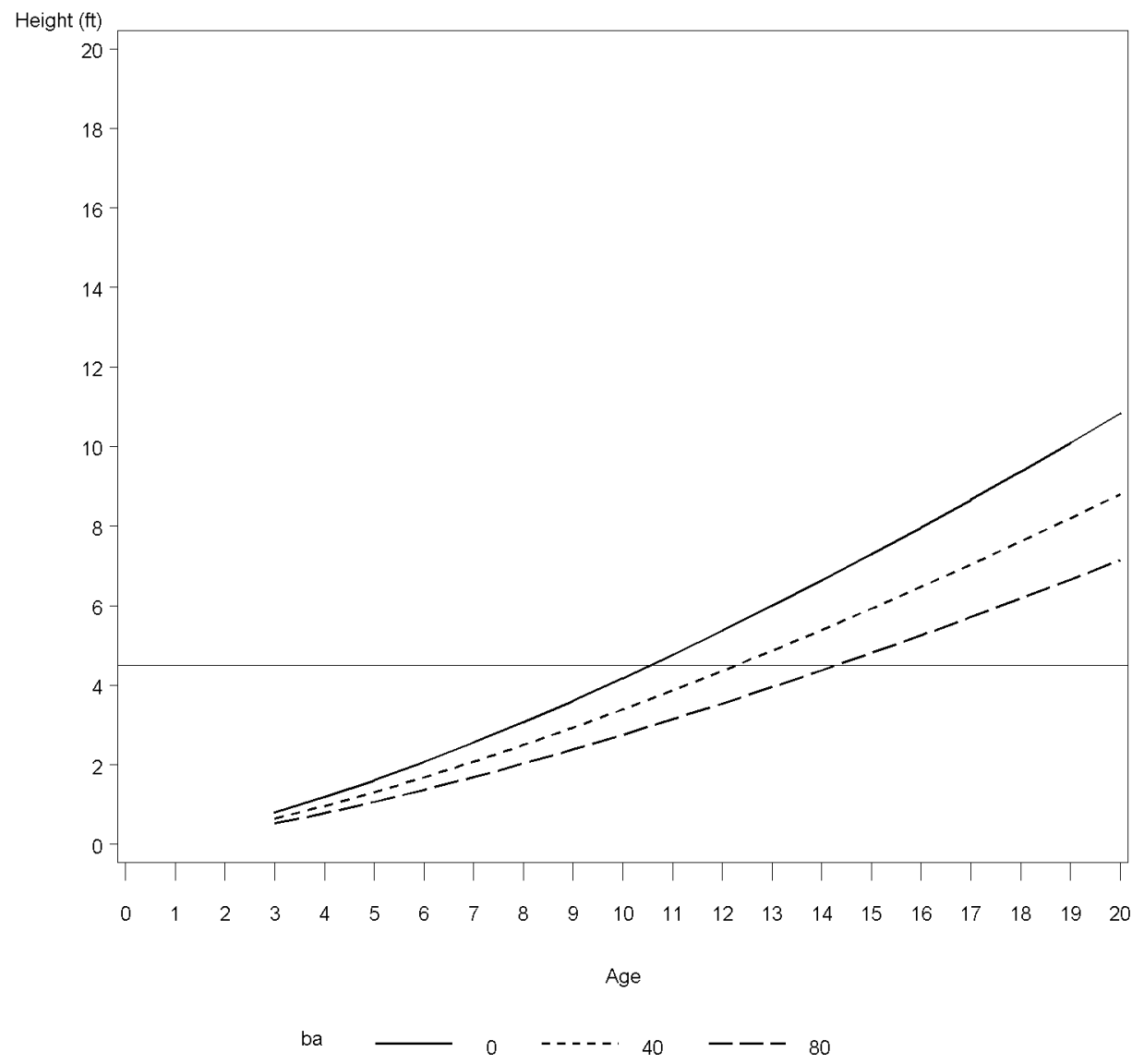

Figure 1. Predicted height-age curves for ponderosa pine with three overstory densities. 

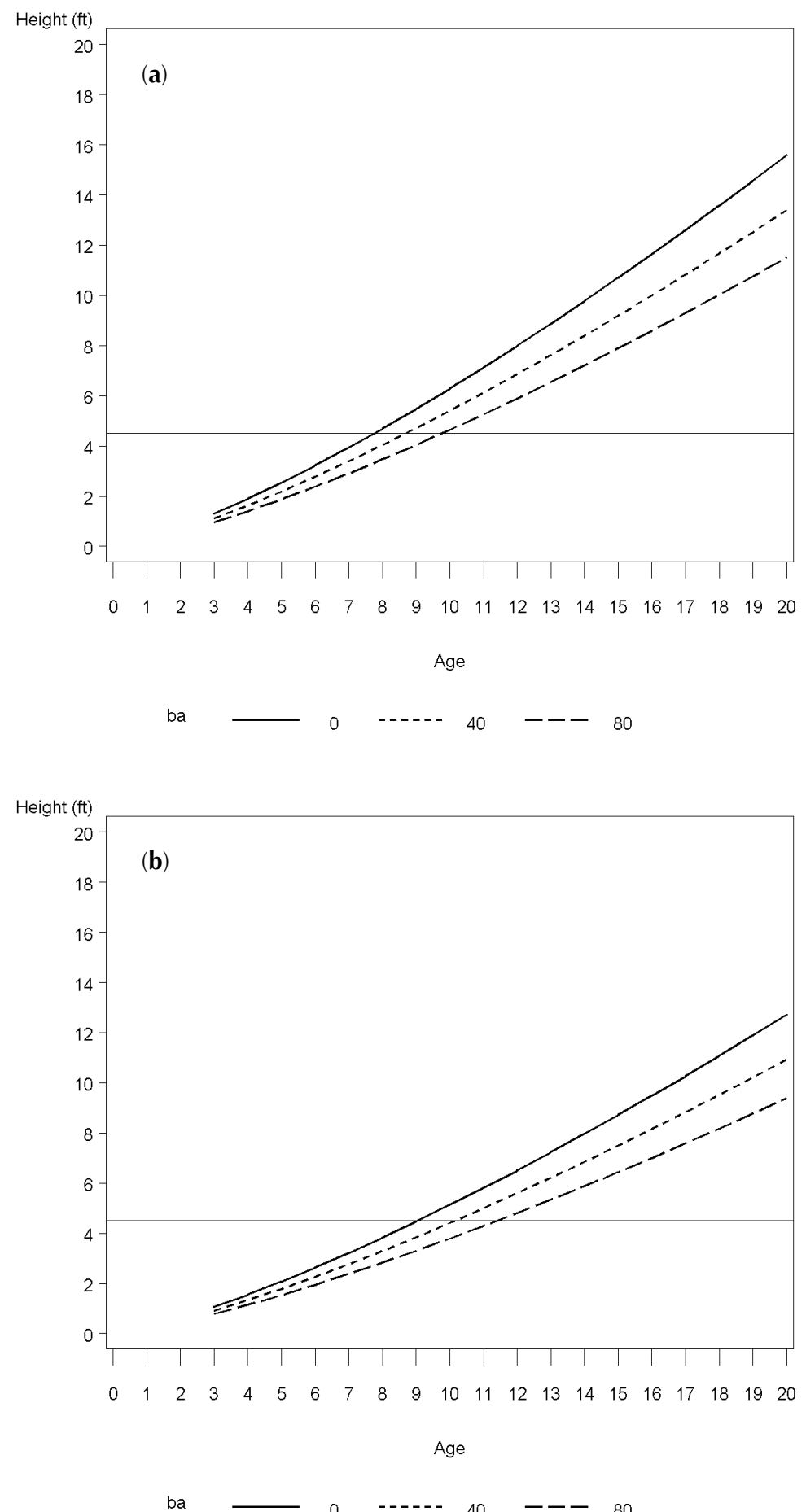

Figure 2. Predicted height-age curves for western larch with three overstory densities and two elevations: (a) 35 and (b) 50. 


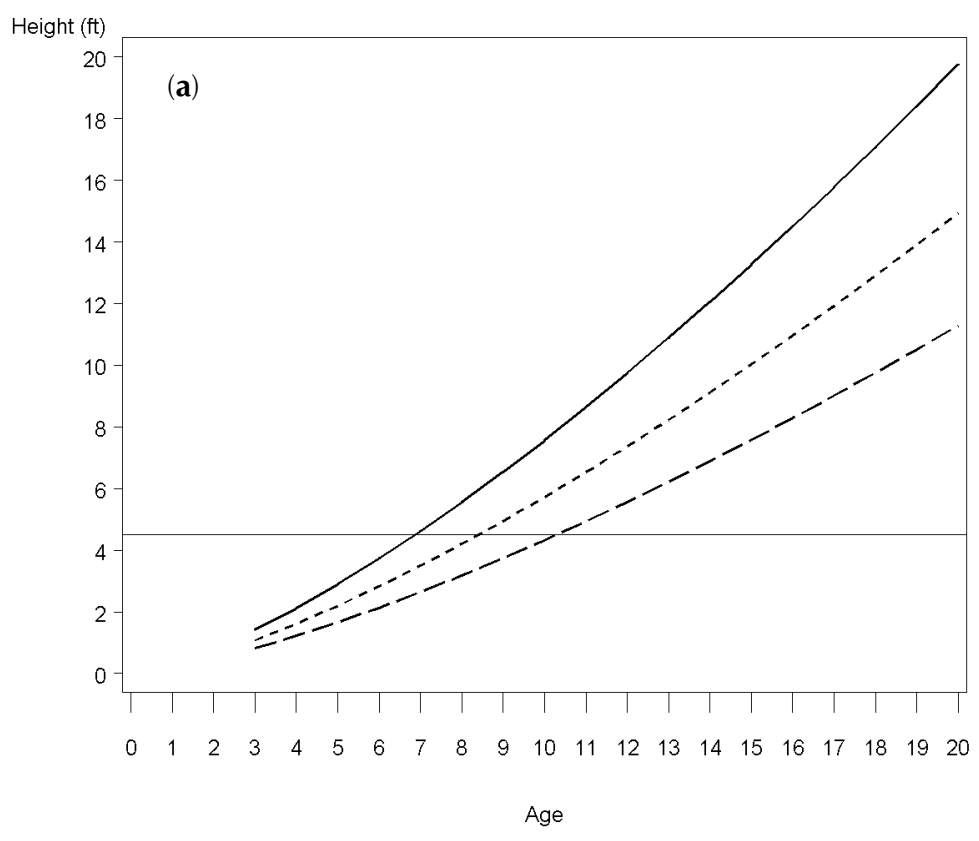

ba
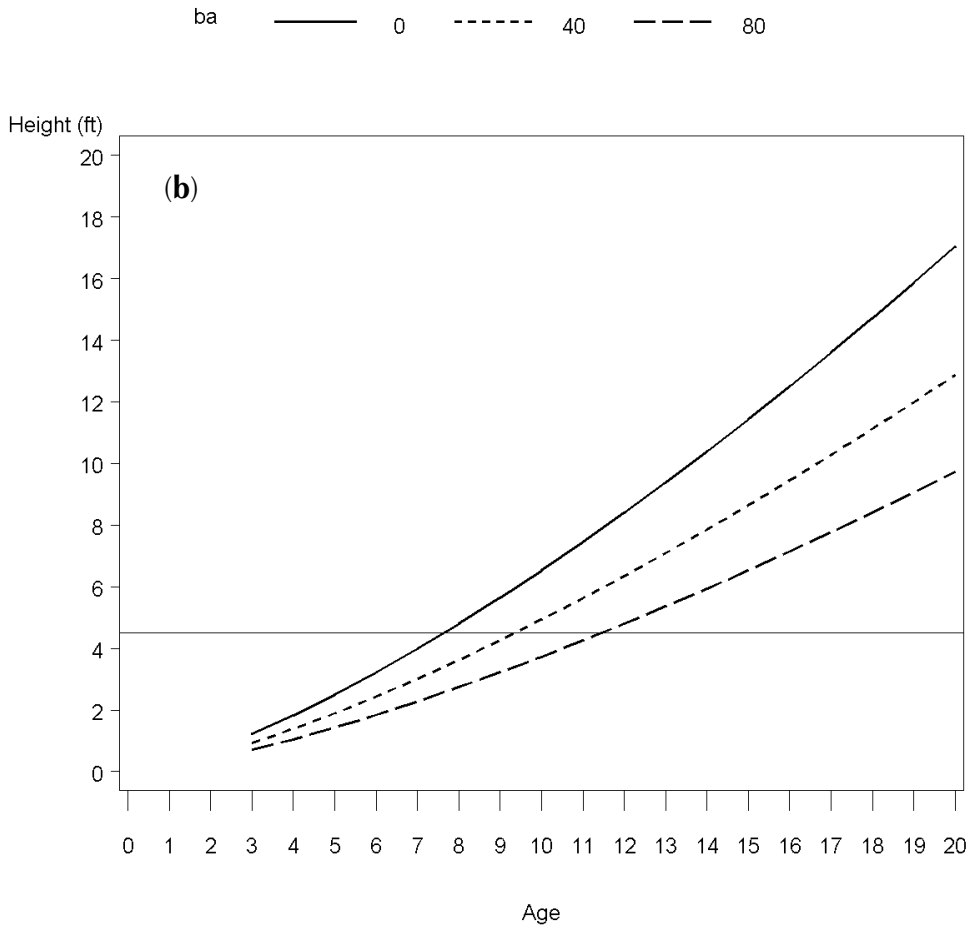

ba

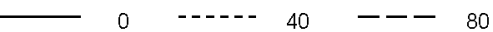

Figure 3. Predicted height-age curves for lodgepole pine with three overstory densities and two elevations: (a) 35 and (b) 50. 


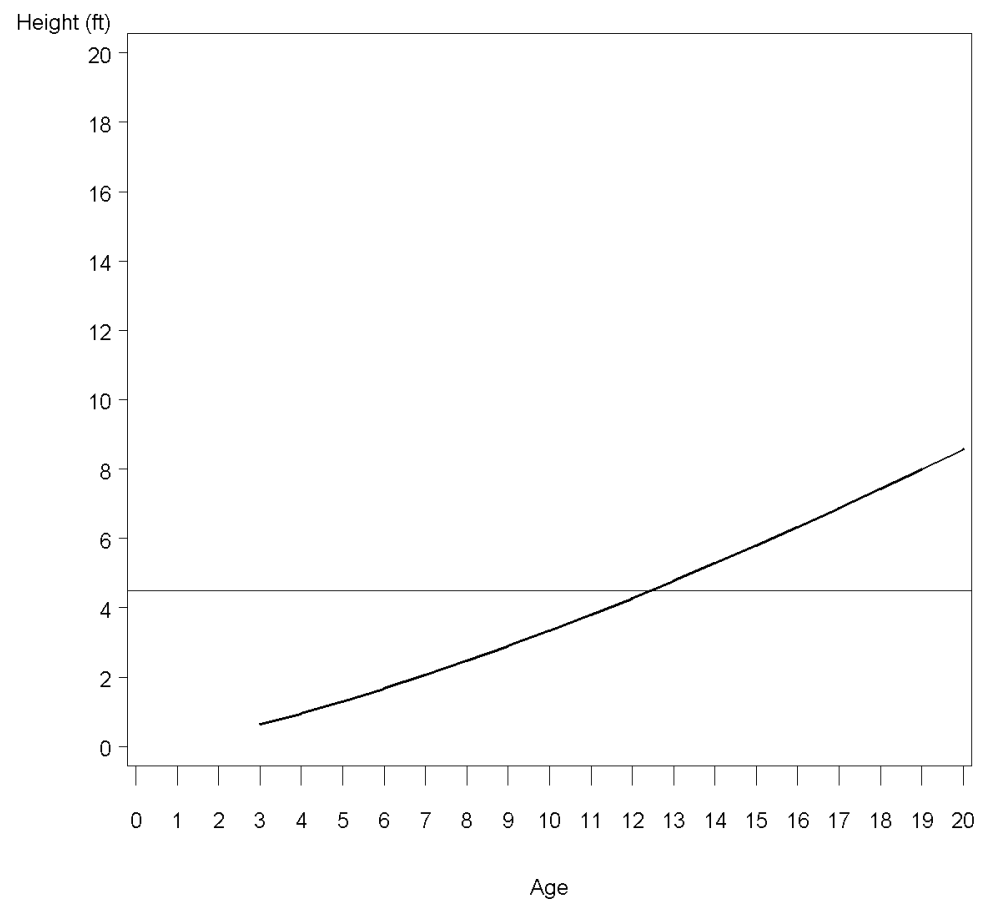

Figure 4. Predicted height-age curve for Engelmann spruce.

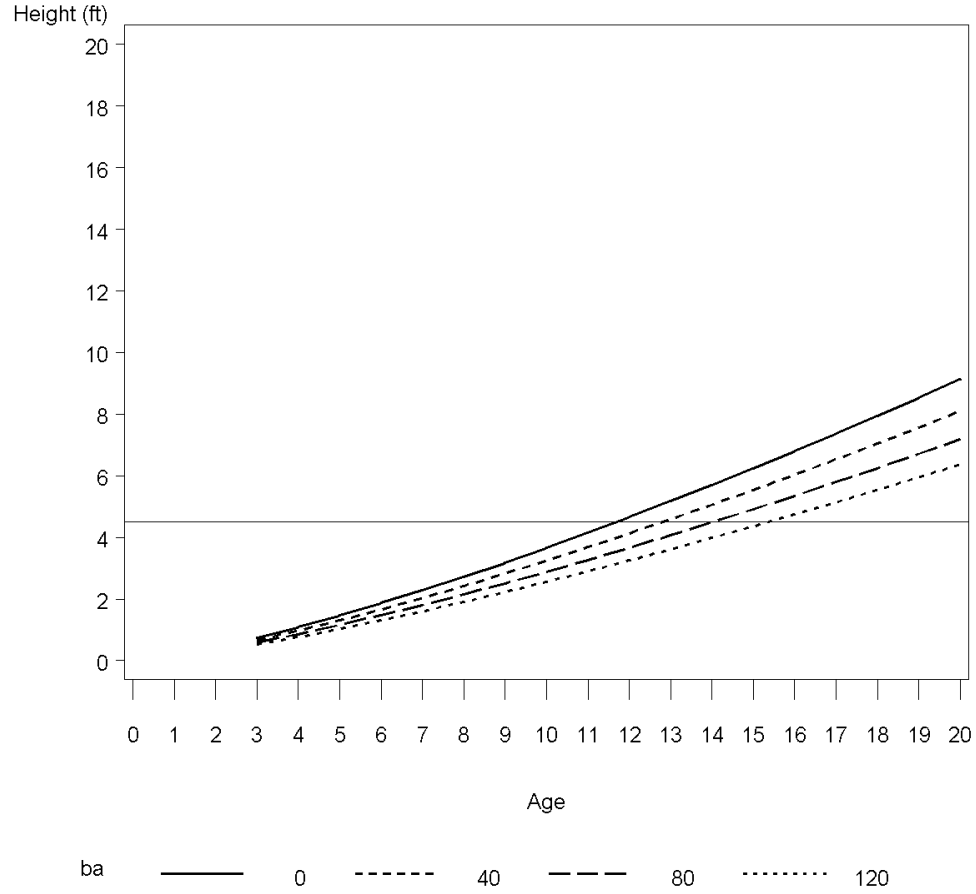

Figure 5. Predicted height-age curves for Douglas-fir with four overstory densities. 


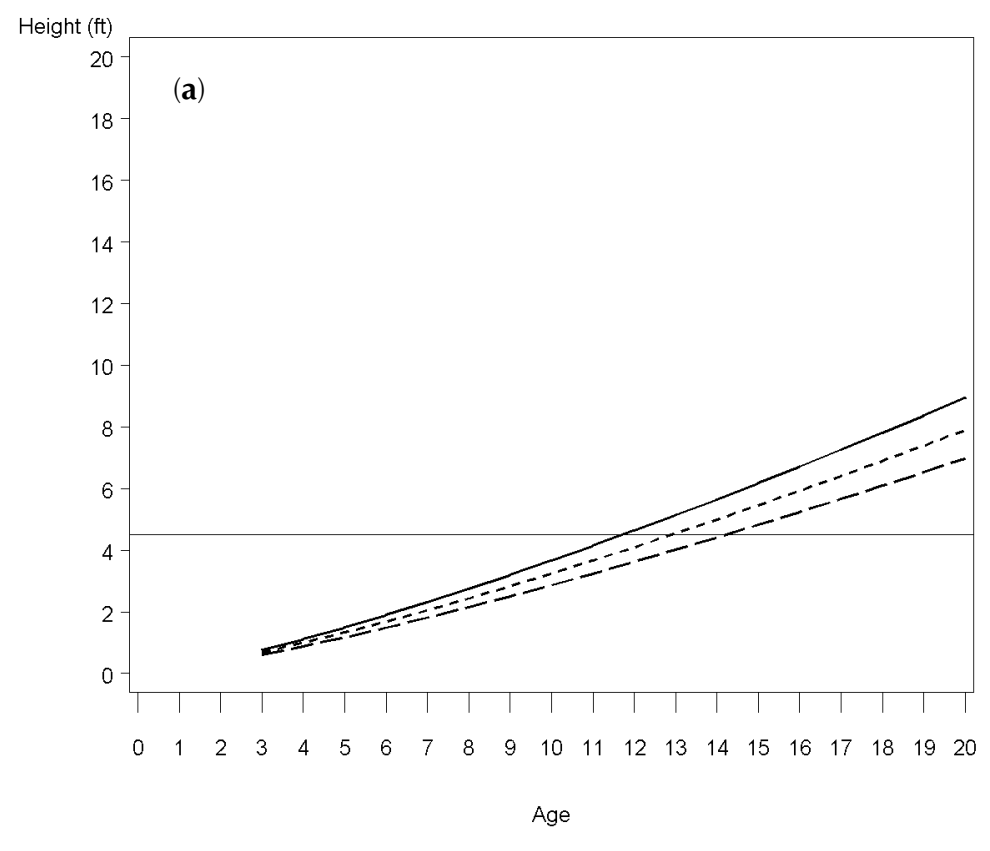

ba $\longrightarrow \quad 0 \quad-\cdots 40 \quad--18$

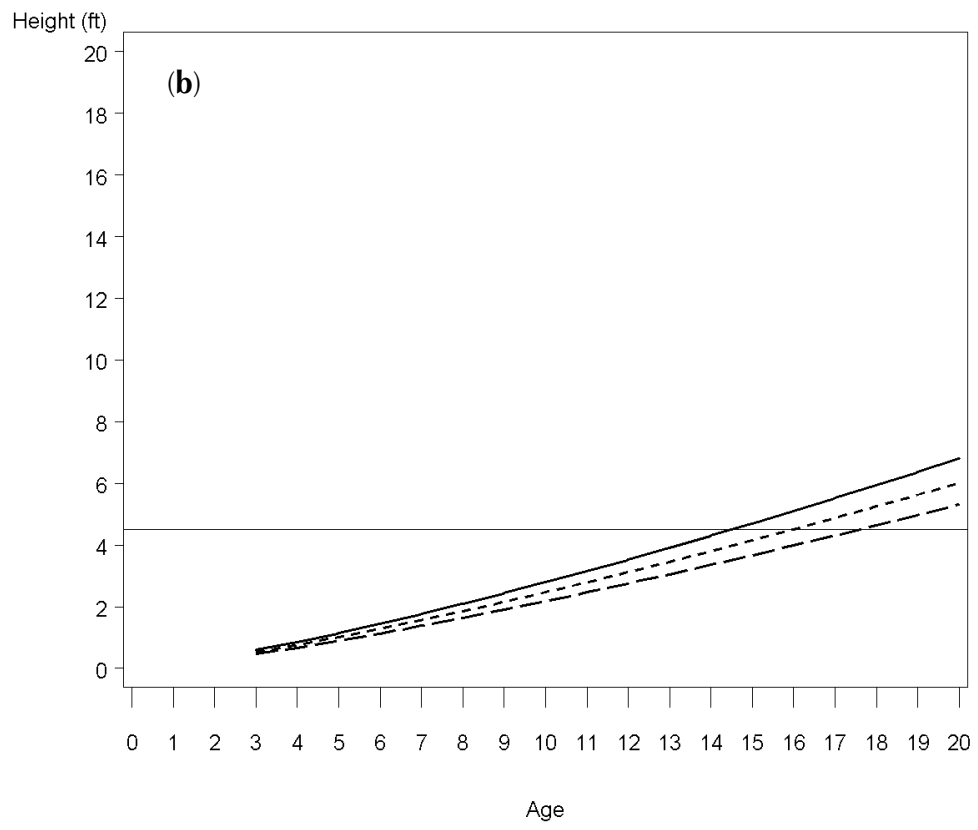

ba $\longrightarrow \quad 0 \quad----40 \quad---80$

Figure 6. Predicted height-age curves for western white pine with three overstory densities and two elevations: (a) 35 and (b) 50. 


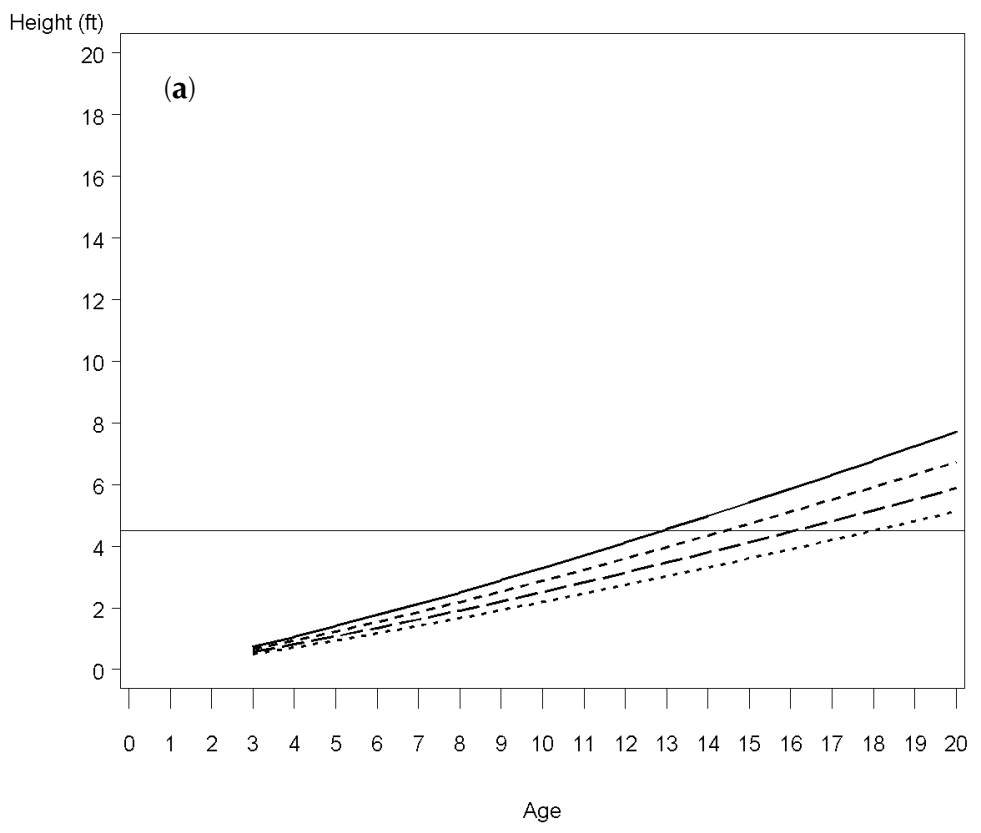

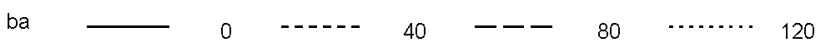

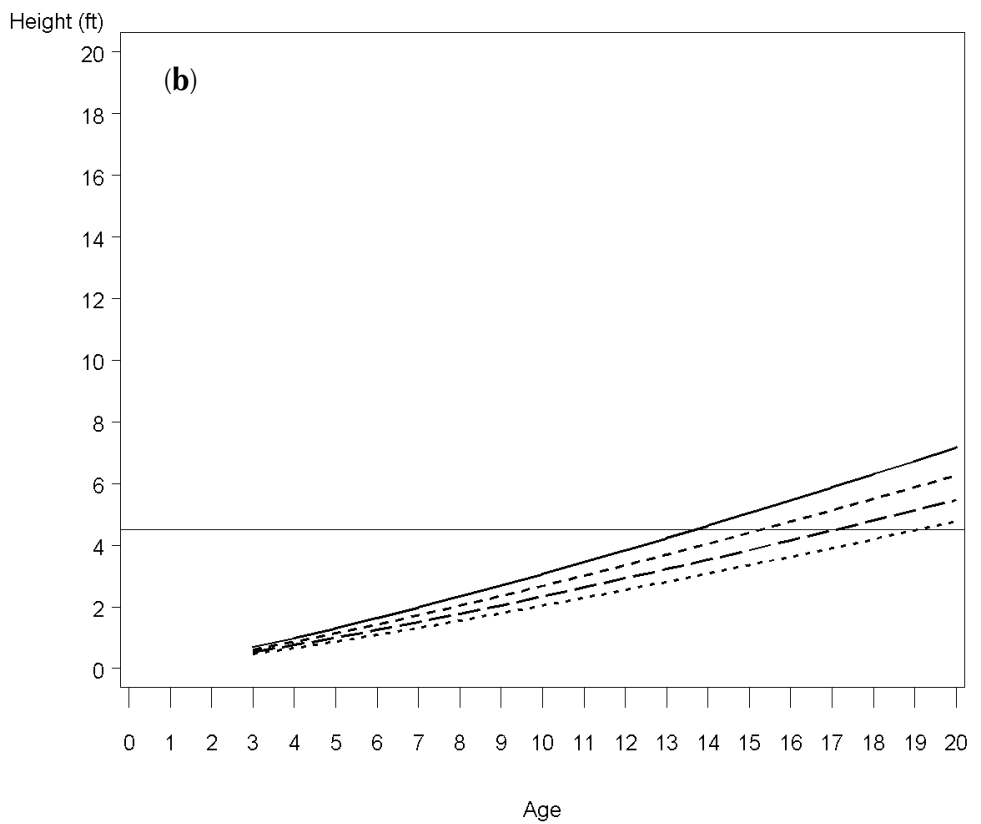

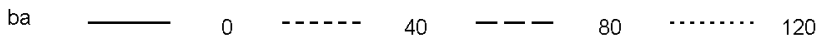

Figure 7. Predicted height-age curves for grand fir with four overstory densities and two elevations: (a) 35 and (b) 50. 

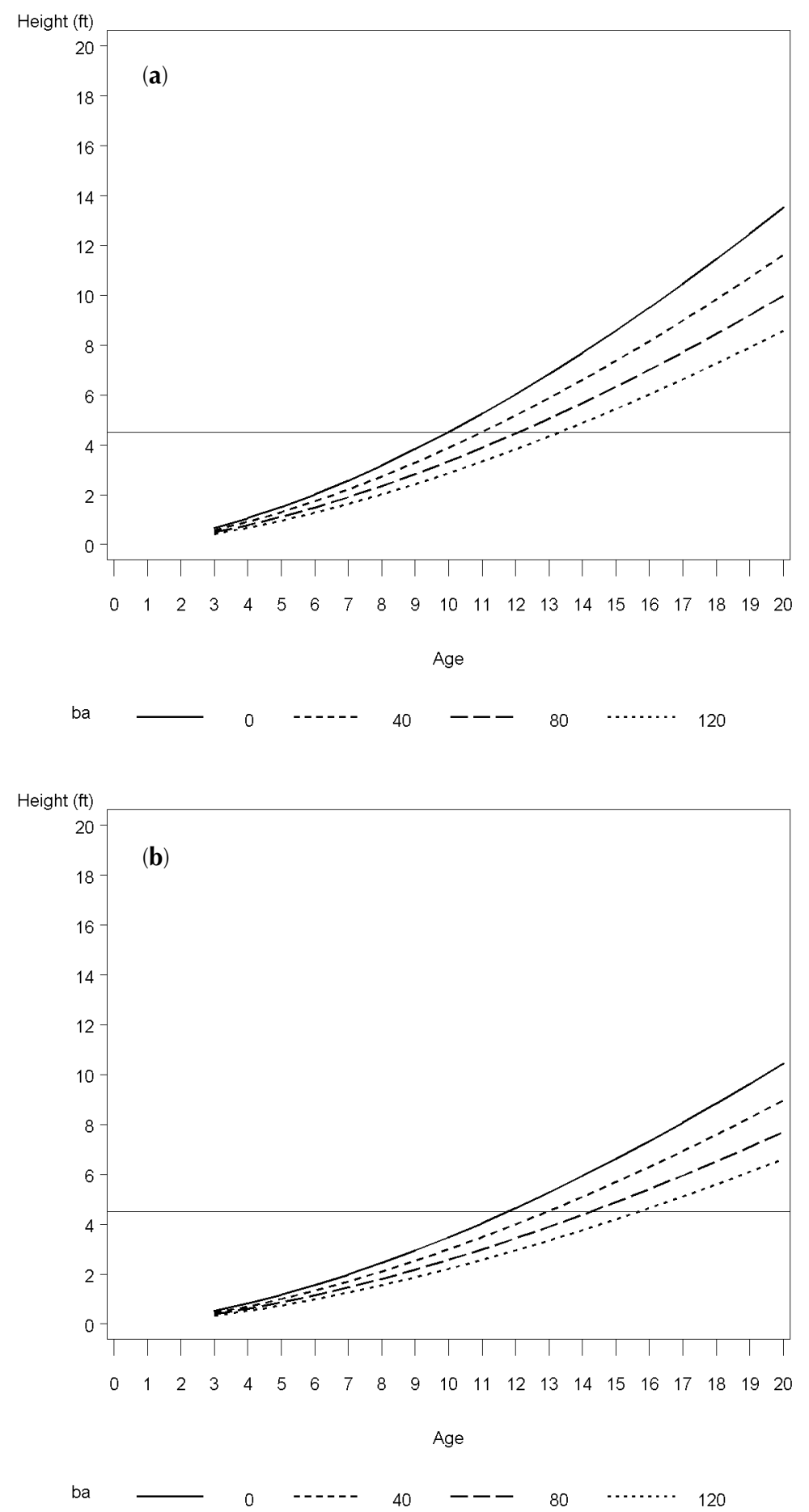

Figure 8. Predicted height-age curves for western hemlock with four overstory densities and two elevations: (a) 35 and (b) 50. 


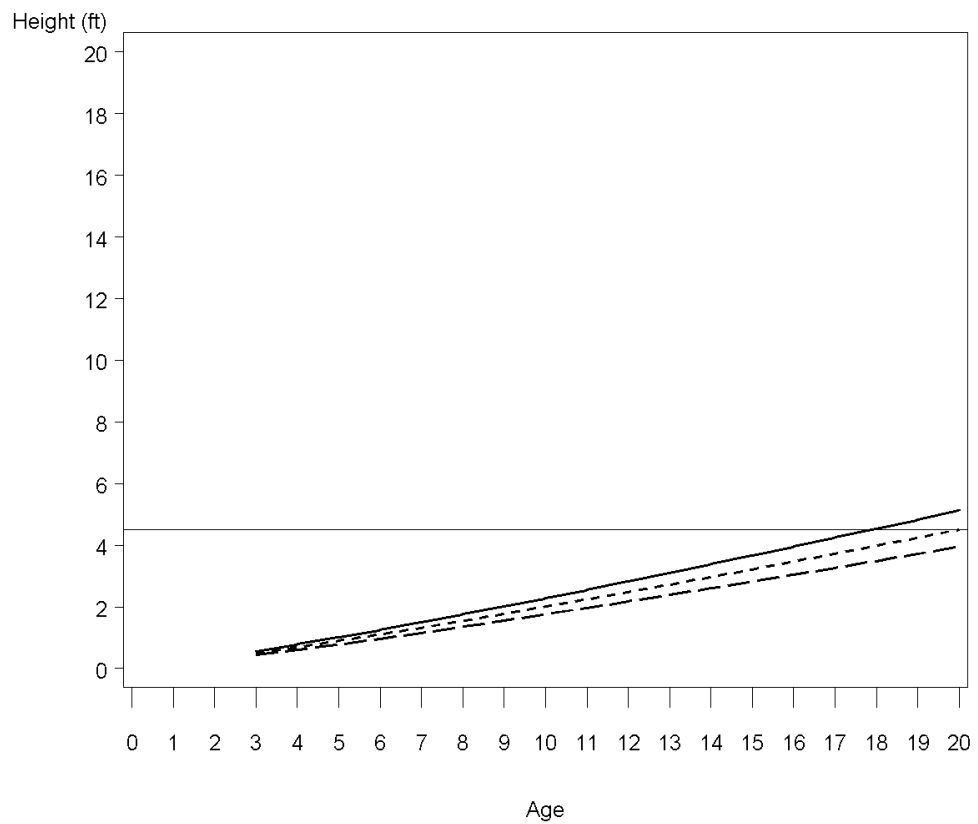

ba $\longrightarrow \quad 0 \quad \cdots-\cdots 40$

Figure 9. Predicted height-age curves for subalpine fir with three overstory densities. 


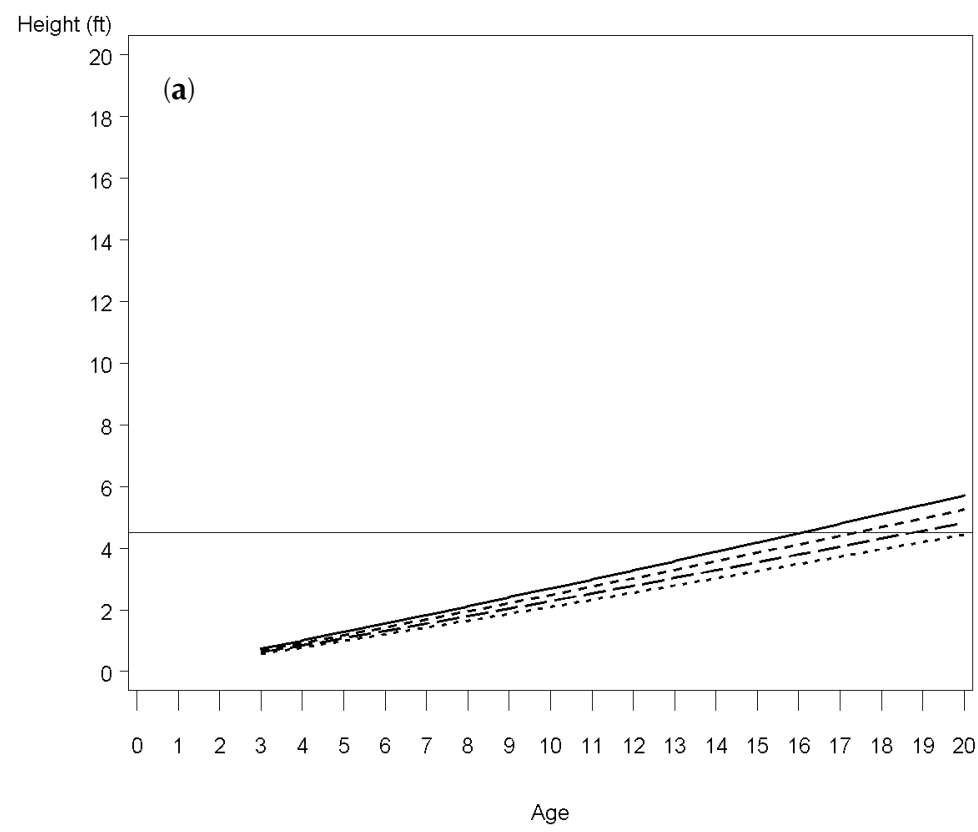

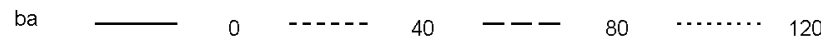

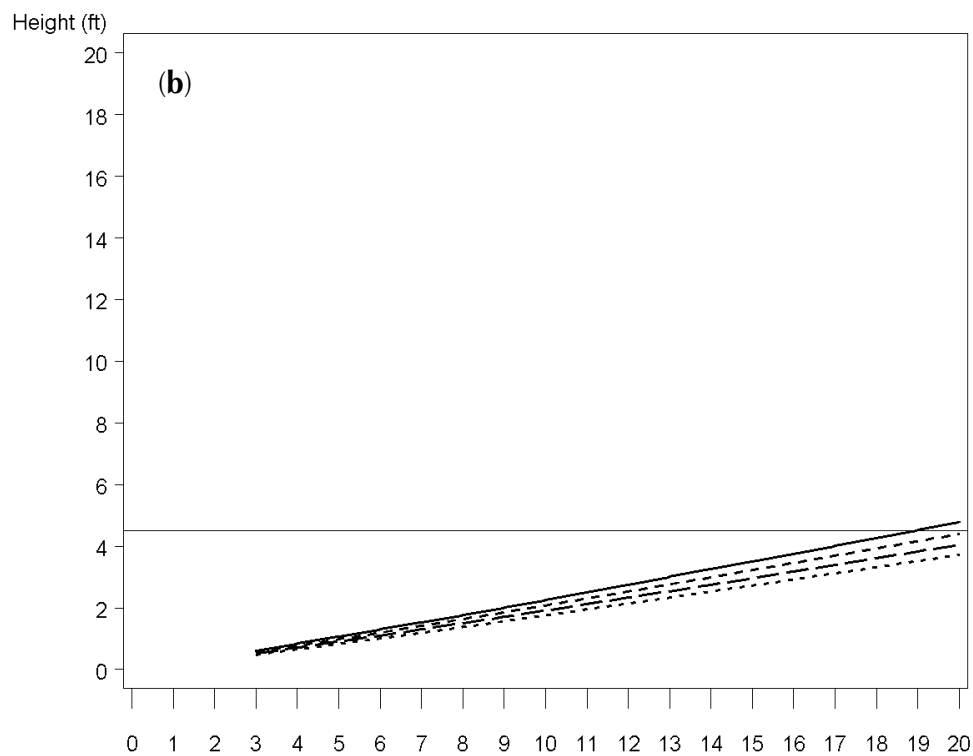

Age

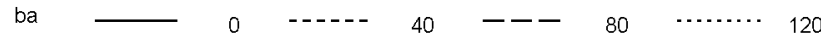

Figure 10. Predicted height-age curves for western redcedar with four overstory densities and two elevations: (a) 35 and (b) 50. 
Table 5. Predicted ages to breast height using equations* in Table 4.

\begin{tabular}{|c|c|c|c|c|c|}
\hline \multirow[b]{2}{*}{ Species } & \multirow[b]{2}{*}{ Elevation } & \multicolumn{4}{|c|}{ Residual basal area (ft²/acre) } \\
\hline & & 0 & 40 & 80 & 100 \\
\hline Ponderosa pine & n.s. & 10.6 & 12.3 & 14.3 & $\mathrm{n} / \mathrm{a}$ \\
\hline Western larch & $\begin{array}{l}35 \\
50\end{array}$ & $\begin{array}{l}7.7 \\
9.0\end{array}$ & $\begin{array}{r}8.7 \\
10.2\end{array}$ & $\begin{array}{r}9.8 \\
11.4\end{array}$ & $\begin{array}{l}\mathrm{n} / \mathrm{a} \\
\mathrm{n} / \mathrm{a}\end{array}$ \\
\hline Lodgepole pine & $\begin{array}{l}35 \\
50\end{array}$ & $\begin{array}{l}6.9 \\
7.6\end{array}$ & $\begin{array}{l}8.4 \\
9.4\end{array}$ & $\begin{array}{l}10.3 \\
11.5\end{array}$ & $\begin{array}{l}n / a \\
n / a\end{array}$ \\
\hline Engelmann spruce & n.s. & 12.5 & 12.5 & 12.5 & $\mathrm{n} / \mathrm{a}$ \\
\hline Douglas-fir & n.s. & 11.7 & 12.8 & 14.0 & 15.4 \\
\hline Western white pine & $\begin{array}{l}35 \\
50\end{array}$ & $\begin{array}{l}11.7 \\
14.5\end{array}$ & $\begin{array}{l}12.9 \\
16.0\end{array}$ & $\begin{array}{l}14.2 \\
17.6\end{array}$ & $\begin{array}{l}\mathrm{n} / \mathrm{a} \\
\mathrm{n} / \mathrm{a}\end{array}$ \\
\hline Grand fir & $\begin{array}{l}35 \\
50\end{array}$ & $\begin{array}{l}12.9 \\
13.7\end{array}$ & $\begin{array}{l}14.4 \\
15.3\end{array}$ & $\begin{array}{l}16.1 \\
17.1\end{array}$ & $\begin{array}{l}18.0 \\
19.1\end{array}$ \\
\hline Western hemlock & $\begin{array}{l}35 \\
50\end{array}$ & $\begin{array}{l}10.0 \\
11.8\end{array}$ & $\begin{array}{l}11.0 \\
12.9\end{array}$ & $\begin{array}{l}12.1 \\
14.2\end{array}$ & $\begin{array}{l}13.3 \\
15.7\end{array}$ \\
\hline Subalpine fir & n.s. & 17.9 & 20.0 & 22.4 & $\mathrm{n} / \mathrm{a}$ \\
\hline Western redcedar & $\begin{array}{l}35 \\
50\end{array}$ & $\begin{array}{l}16.0 \\
18.9\end{array}$ & $\begin{array}{l}17.3 \\
20.4\end{array}$ & $\begin{array}{l}18.7 \\
22.1\end{array}$ & $\begin{array}{l}20.3 \\
23.9\end{array}$ \\
\hline
\end{tabular}

Table 5 shows predicted ages to breast height, by species, for the same two elevations and for three to four levels of residual overstory basal area used to develop Figures 1 through 10. The equations in Table 4 are solved for a $4.5 \mathrm{ft}$ tall tree. With other variables held constant, the species that reach $4.5 \mathrm{ft}$ most rapidly are western larch and lodgepole pine, while subalpine fir and western redcedar take the longest. Increasing residual overstory density is associated with additional years to reach breast height for all species except Engelmann spruce.

The appendix shows examples of how to use the equations. Prior to transformation of predicted height to the original units (ft), estimates must be multiplied by a log bias correction factor. These correction factors are species-specific and are shown at the bottom of Table 4. The log bias correction is necessary to avoid underestimating heights when transforming log models back to the original units of measurement (Baskerville 1972).

\section{Discussion}

Even though western hemlock has the largest coefficient for $\ln ($ age $)$ in Table 4, trees are taller at a given age for western larch and lodgepole pine (Figures 8, 2, and 3). This occurs because the intercept coefficient for western hemlock is a larger negative number than the intercept terms for western larch and lodgepole pine. The net effect is that heights of western hemlock are initially shorter than western larch and lodgepole pine, but the slope of the western hemlock curve is steeper than western larch and lodgepole pine. Even with a steeper curve, heights of western hemlock do not reach heights of western larch and lodgepole pine during the 20-yr time period.

An independent variable used in the analyses was the number of years from the disturbance to the germination of the tree (Table 3). This variable, called delay, was never significant in the equations that predicted height. Conventional wisdom suggests that any delay to germination would leave trees behind competitors that germinated earlier, resulting 
in differentiation of tree sizes over time. The trees chosen for sampling in this study were the best (tallest) trees on the plot, so they may not have been negatively affected by competition. Even though there may have been a delay between disturbance and germination for best trees, this delay was probably not as long as for other trees of the same species on the plot. It should be noted that delay to germination is still detrimental if the goal is prompt regeneration of an area; for example, a 5-yr delay means that $5 \mathrm{yr}$ of growth is lost.

Berglund and others (2008) estimated the number of years to breast height for conifers in the northern Rocky Mountains. Their sample trees came from stand examination data, which included all the conifers shown in Table 1. They had 39,200 trees with heights between 4.0 and $5.0 \mathrm{ft}$. Their average number of years to breast height was most often longer than averages shown in Table 5 because their data came from a wide range of stand ages (for example, stands greater than $20 \mathrm{yr}$ old) and disturbance histories. Also, their data included ingrowth trees, which are trees that become established beyond the regeneration period triggered by a disturbance event.

Despite differences in the design between the two studies, results are similar. Table 6 shows median number of years to breast height from Berglund and others (2008) versus species averages calculated from Table 5. For this comparison, medians (50th percentile) reported by Berglund and others (2008) for northern Idaho and western Montana were averaged by species so that their averages could be compared to data collected for this study. Four of the 10 species agree within $2 \mathrm{yr}$ of each other (western larch, lodgepole pine, Douglas-fir, and grand fir), and 6 of the 10 species agree within $3 \mathrm{yr}$ of each other (western larch, lodgepole pine, Douglas-fir, grand fir, western hemlock, and subalpine fir). Four species (ponderosa pine, Engelmann spruce, western white pine, and western redcedar) differ by 4.2 to 4.9 yr. For ponderosa pine, western white pine, and western redcedar, predicted ages at breast height using equations in Table 4 exceeded average medians calculated from Berglund and others (2008).

The difference of $4.7 \mathrm{yr}$ for ponderosa pine is due to the inclusion of the coefficient for the Payette NF (-0.4394) in the calculation of ages to breast height that is reported in Table 4. Berglund and others (2008) do not have data for the Payette NF. When the ponderosa pine equation is re-run for the Nez Perce NF (where Berglund and others [2008] do have data), predicted ages to breast height for ponderosa pine are $8.9 \mathrm{yr}$ for $0 \mathrm{ft}^{2}$ of basal area, $10.4 \mathrm{yr}$ for $40 \mathrm{ft}^{2}$ of basal area, and $12.1 \mathrm{yr}$ for $80 \mathrm{ft}^{2}$ of basal area. The overall average is $10.5 \mathrm{yr}$, which is within $3 \mathrm{yr}$ of the average median value in Berglund and others (2008).

Table 6. Mean number of years to reach breast height.

\begin{tabular}{lcc}
\hline Species & $\begin{array}{c}\text { Means calculated } \\
\text { from Table 5 }\end{array}$ & $\begin{array}{c}\text { Mean medians from } \\
\text { Berglund and others (2008) }\end{array}$ \\
\hline Ponderosa pine & 12.4 & 7.7 \\
Western larch & 9.5 & 8.6 \\
Lodgepole pine & 9.0 & 9.5 \\
Engelmann spruce & 12.5 & 17.4 \\
Douglas-fir & 13.5 & 12.4 \\
Western white pine & 14.5 & 9.4 \\
Grand fir & 15.8 & 14.4 \\
Western hemlock & 12.6 & 15.0 \\
Subalpine fir & 20.1 & 22.4 \\
Western redcedar & 19.7 & 15.5 \\
\hline
\end{tabular}


Berglund and others (2008) reported an average median of $9.4 \mathrm{yr}$ to breast height for western white pine, while the average from Table 5 is $14.5 \mathrm{yr}$. The discrepancy may be due to the method for aging trees. In the inventory methods described by Berglund and others (2008), field crews either severed the tree at the root collar and counted annual rings or they counted the number of whorls. Counting whorls on western white pine can be problematic, especially as the trees become taller and it becomes difficult to determine the location of whorls near the ground. Haig (1932) reports that dominant white pine take an average of 5 $\mathrm{yr}$ to reach $1 \mathrm{ft}$ tall ( $4 \mathrm{yr}$ on better sites and $6 \mathrm{yr}$ on poorer sites) in even-age second-growth stands. He reports ages at breast height of $9 \mathrm{yr}$ on good sites, $11 \mathrm{yr}$ on average sites, and 14 $\mathrm{yr}$ on poor sites. This range of 9 to $14 \mathrm{yr}$ is in good agreement with predictions for white pine in Table 5 that use no overstory density.

The difference in age to breast height for western redcedar is $4.2 \mathrm{yr}$ (19.7 yr versus 15.5 yr; Table 6). For this species, the discrepancy may be due to difficulties counting the number of whorls. Parker and Johnson (1987) investigated the problem of backdating heights on western redcedar. They found that annual terminal increments can be determined for the previous 3 to $5 \mathrm{yr}$. Because western redcedar lack a major whorl of branches at the beginning of each year's growth, ocular estimates of tree age would tend to underestimate tree age. Therefore, aging the tree at groundline should be more accurate than counting whorls.

For Engelmann spruce, Berglund and others (2008) reported an average of $17.4 \mathrm{yr}$ to breast height, while the average from Table 5 is $12.5 \mathrm{yr}$. The difference may be due to our inclusion of the coefficient for burn site preparation (0.2895). The average for mechanical site preparation would be $13.9 \mathrm{yr}$ and $15.4 \mathrm{yr}$ for no site preparation, which are closer to the average reported by Berglund and others (2008).

There was also good agreement between the two studies on which species reached breast height quickly or slowly (Table 6). Shade-intolerant ponderosa pine, western larch, and lodgepole pine reached breast height relatively quick, while shade-tolerant subalpine fir took about twice as long to reach breast height.

Height-age relationships for these data could differ from other disturbance types. Data reported here are for operationally harvested and site prepared stands. Height-age relationships might be different for regeneration following wildfires where there is a flush of nutrients and where competing vegetation has been burned. Likewise, data from areas where overstory trees are killed by bark beetles may differ from data in this study because overstory trees continue to cast shade for many years in beetle-killed areas.

Results of this study could also differ from other techniques used to determine heightage relationships in young trees. One technique to determine total tree age from breast height age is to sample large trees with either increment cores or by severing the tree at groundline and at $4.5 \mathrm{ft}$. Sampling larger trees could give different answers than sampling regeneration-size trees because the larger trees are usually the survivors from denser stands that have self-thinned due to natural causes. Large trees could be those that exhibit the best early growth or they could be slower growing survivors that were spared from insects, diseases, or secondary succession. Conversely, randomly sampling regeneration-size trees could result in including many trees that will not become part of the eventual overstory. Our technique of sampling the best (tallest) trees meant that trees with the highest likelihood of reaching the overstory were used to develop height-age relationships.

Equations in Table 4 can be used to predict height-age relationships for 10 northern Rocky Mountain conifer species when the disturbance event is harvesting. Most of the trees in the sample are natural regeneration. Equations can be used for stands up to about $15 \mathrm{yr}$ old, with various amounts of residual overstory density, 4 site preparation methods, and 5 habitat type series. These equations are applicable to pre-climate change conditions, and, therefore, are valuable as reference data. 


\section{References}

Baskerville, G. L. 1972. Use of logarithmic regression in the estimation of plant biomass. Canadian Journal of Forestry. 2:49-53.

Berglund, D.; Bush, R.; Zack, A. 2008. Estimates of years to breast-height for large conifer tree species in the Northern Region. Rep. 08-03 v3.0. Missoula, MT: USDA Forest Service, Region One. 20 p.

Cooper, S. V.; Neiman, K. E.; Roberts, D. W. 1991. Forest habitat types of northern Idaho: A second approximation. Gen. Tech. Rep. INT-236. Ogden, UT: USDA Forest Service, Intermountain Research Station. 143 p.

Daubenmire, R. 1959. A canopy-coverage method of vegetation analysis. Northwest Science. 33:43-64.

Daubenmire, R. 1966. Vegetation: identification of typal communities. Science. 151:291-298.

Ferguson, D. E.; Carlson, C. E. 1993. Predicting regeneration establishment with the Prognosis Model. Res. Pap. INT-467. Ogden, UT: USDA Forest Service, Intermountain Research Station. $54 \mathrm{p}$.

Ferguson, D. E.; Stage, A. R.; Boyd, R. J. 1986. Predicting regeneration in the grand fir-cedar-hemlock ecosystem of the northern Rocky Mountains. Forest Science Monograph 26. Washington, DC: Society of American Foresters. 41 p.

Haig, I. T. 1932. Second-growth yield, stand, and volume tables for the western white pine type. Tech. Bull. 323. Washington, DC: U.S. Department of Agriculture. 67 p.

Kirk, R. E. 1982. Experimental design, second edition. Brook/Cole Publishing Company, Monterey, CA. $911 \mathrm{p}$.

Littell, R. C.; Milliken, G. A.; Stroup, W. W.; Wolfinger, R. D. 1996. SAS system for mixed models. SAS Institute, Cary, NC. 633 p.

Moeur, M. 1985. COVER: A user's guide to the CANOPY and SHRUBS extension of the Stand Prognosis Model. Gen. Tech. Rep. INT-190. Ogden, UT: USDA Forest Service, Intermountain Research Station. 49 p.

Parker, T.; Johnson, F. D. 1987. Branching and terminal growth of western redcedar. Northwest Science. 61:7-12.

Pfister, R. D.; Kovalchik, B. L.; Arno, S. F.; Presby, R. C. 1977. Forest habitat types of Montana. Gen. Tech. Rep. INT-34. Ogden, UT: USDA Forest Service, Intermountain Forest and Range Experiment Station. 174 p.

Rehfeldt, G. E.; Ferguson, D. E.; Crookston, N. L. 2008. Quantifying the abundance of co-occurring conifers along Inland Northwest (USA) climate gradients. Ecology. 89:2127-2139.

Stage, A. R. 1976. An expression for the effect of aspect, slope, and habitat type on tree growth. Forest Science. 22:457-460.

Steele, R.; Pfister, R. D.; Ryker, R. A.; Kittams, J. A. 1981. Forest habitat types of central Idaho. Gen. Tech. Rep. INT-114. Ogden, UT: USDA Forest Service, Intermountain Forest and Range Experiment Station. 138 p.

Wykoff, W. R.; Crookston, N. L.; Stage, A. R. 1982. User's guide to the Stand Prognosis Model. Gen. Tech. Rep. INT-133. Ogden, UT: USDA Forest Service, Intermountain Forest and Range Experiment Station. $112 \mathrm{p}$

Wykoff, W. R. 1986. Supplement to the user's guide for the Stand Prognosis Model-version 5.0. Gen. Tech. Rep. INT-208. Ogden, UT: USDA Forest Service, Intermountain Research Station. $36 \mathrm{p}$. 


\section{Appendix. Examples of using height-age equations shown in Table 4.}

Example 1. Predict height of 15-yr-old ponderosa pine on a grand fir habitat type,

Clearwater NF, no residual overstory, and mechanical site preparation. The value 1.28 is the $\log$ bias correction factor for the ponderosa pine equation.

$$
\begin{aligned}
& \text { Height }=1.28 *[\exp (-1.7936+1.3737 * \ln (\text { age })-0.0052 * \text { ba }+0.0885+0.1642)] \\
& \text { Height }=11.3 \mathrm{ft}
\end{aligned}
$$

Example 2. Predict the age at which a western larch will reach $4.5 \mathrm{ft}$, residual overstory $=20 \mathrm{ft}^{2} /$ acre, elev $=35$, Lolo NF. The value 1.27 is the $\log$ bias correction factor for the western larch equation.

Height $=1.27 *[\exp (-0.8617+1.3093 * \ln ($ age $)-0.0038 *$ ba $-0.0136 *$ elev $0.0770)$ ]

Set Height $=4.5 \mathrm{ft}$, and solve for age

$$
\begin{aligned}
& \text { age }=\exp [(\ln (4.5 / 1.27)+0.8617+0.0038 * \mathrm{ba}+0.0136 * \text { elev }+0.0770) / 1.3093] \\
& \text { age }=8.2
\end{aligned}
$$




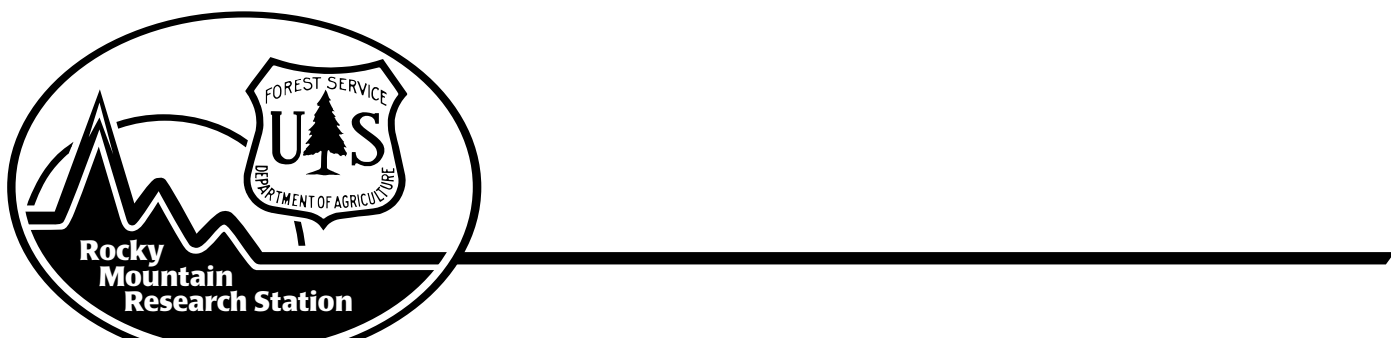

The Rocky Mountain Research Station develops scientific information and technology to improve management, protection, and use of the forests and rangelands. Research is designed to meet the needs of the National Forest managers, Federal and State agencies, public and private organizations, academic institutions, industry, and individuals. Studies accelerate solutions to problems involving ecosystems, range, forests, water, recreation, fire, resource inventory, land reclamation, community sustainability, forest engineering technology, multiple use economics, wildlife and fish habitat, and forest insects and diseases. Studies are conducted cooperatively, and applications may be found worldwide.

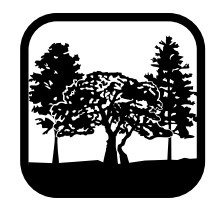

\author{
Station Headquarters \\ Rocky Mountain Research Station \\ 240 W Prospect Road \\ Fort Collins, CO 80526 \\ (970) 498-1100
}

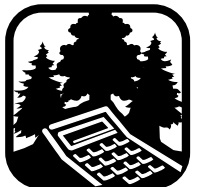

Research Locations

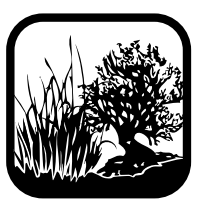

Flagstaff, Arizona

Fort Collins, Colorado

Boise, Idaho

Moscow, Idaho

Bozeman, Montana

Missoula, Montana
Reno, Nevada

Albuquerque, New Mexico

Rapid City, South Dakota

Logan, Utah

Ogden, Utah

Provo, Utah

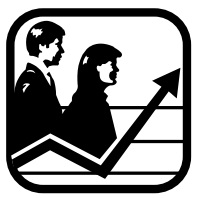

The U.S. Department of Agriculture (USDA) prohibits discrimination in all its programs and activities on the basis of race, color, national origin, age, disability, and where applicable, sex, marital status, familial status, parental status, religion, sexual orientation, genetic information, political beliefs, reprisal, or because all or part of an individual's income is derived from any public assistance program. (Not all prohibited bases apply to all programs.) Persons with disabilities who require alternative means for communication of program information (Braille, large print, audiotape, etc.) should contact USDA's TARGET Center at (202) 720-2600 (voice and TDD). To file a complaint of discrimination, write to USDA, Director, Office of Civil Rights, 1400 Independence Avenue, S.W., Washington, DC 20250-9410, or call (800) 795-3272 (voice) or (202) 720-6382 (TDD). USDA is an equal opportunity provider and employer. 